\title{
PERDA SYARIAH DALAM UPAYA PENINGKATAN DAYA SAING EKONOMI DAERAH
}

\author{
Zavirani Fitrandasari, Ridan Muhtadi, Moh. Nafik H.R \\ Fakultas Ekonomi dan Bisnis Universitas Airlangga \\ Email: ridanmuhtadi@gmail.com
}

\section{Abstract}

The 2014 Law No. 24 makes regional governments have extensive authority in managing their regions. Using this authority, the implementation of regional regulation (perda) in Islamic Sharia is more suitable with Islamic local wisdom. Sharia regulations have indicated a change in legal politics, from the paradigm of legal unification to pluralism. More economists and practitioners are interested in sharia economic as alternative in preventing economic crisis after global financial crisis in 2008. As a result, some regions began to implement sharia economic by providing legal protection to formulate regional regulations. This study aims to analyze "perda" related to the implementation of Islamic Sharia by taking Sharia Economic and Financial Regulations as example. This is a juridical-normative research using primary and secondary legal data. The analytical approach used is content, concept, and case. The results indicate that Sharia Economic Regulations in Indonesia are very important. Moreover, the forecast growth of financial and sharia business industries is quite rapid in East Java. Hence, it is very necessary to accelerate the divine economy to the regions and be able to create an economy in a stable and fair area.

Undang-Undang No 24 Tahun 2014, menjadikan Pemerintah Daerah memiliki kewenangan yang luas dalam pengelolaan didaerahnya. Dengan adanya kewenangan yang luas inilah, maka implementasi Peraturan Daerah (Perda) syariat Islam menjadi lebih sesuai dengan kearifan lokal yang islami. Perda syariah telah menunjukkan terjadinya perubahan politik hukum, dari paradigma unifikasi bukum menjadi pluralisme hukum. Krisis finansial global pada tahun 2008 semakin membuat ekonomi syariah dilirik banyak para ekonom dan praktisi sebagai salah satu alternatif pencegahan krisis ekonomi. Sehingga beberapa daerah mulai menerapkan ekonomi syariah dengan memberikan kepastian payung hukumnya dengan merumuskan peraturan daerah. 
Penelitian ini bertujuan untuk menganalisis Perda terkait dengan pelaksanaan syariah Islam dengan mengambil contoh perda ekonomi dan keuangan syariah. Jenis penelitian ini adalah yuridis-normatif dengan menggunakan data atau bahan bukum primer dan sekunder. Pendekatan analisisyang digunakan adalab isi (konten), konsep dan kasus. Hasil penelitian ini menunjukkan bahwa perda ekonomi syariah di Indonesia adalah hal yang sangat penting. Apalagi melihat forecasting growth industri keuangan maupun bisnis syariah yang cukup pesat di Jawa Timur, maka dirasa sangat perlu adanya upaya akselerasi ekonomi ilabiyah ke daerah-daerah dan mampu menciptakan perekonomian di daerah yang stabil dan adil.

Keywords: politics of law, implementation of sharia regional regulation, and Islamic financial economics

\section{Pendahuluan}

Runtuhnya rezim orde baru pada tahun 1998 merupakan reformasi baru bagi perjuangan demokrasi di Indonesia. Salah satu arus balik gerakan pasca reformasi yang dapat disaksikan saat ini ialah maraknya gerakan formalisasi syariat Islam di berbagai daerah ${ }^{1}$, karena hal ini, PEW Research Center (2011) Indonesia sebagai salah satu negara besar di dunia dengan jumlah penduduk muslim terbanyak.

Pemerintah mempunyai tujuan untuk menjunjung tinggi kemakmuran rakyatnya menjadi kewajiban pemerintah dalam mensejahterakan rakyat di setiap daerahnya. Keberadaan otonomi daerah di Indonesia telah menjadi konsensus nasional. Adanya otonomi daerah untuk menjamin efektifitas dan efisiensi penyelenggaraan pemerintahan.

Sejak disahkannya Undang-Undang Undang-Undang No 23 Tahun 2014 tentang Pemerintah Daerah sebagai pelaksanaan dari otonomi daerah, Pemerintah Daerah memiliki kewenangan yang luas dalam mengelola daerahnya. Kewenangan yang luas inilah, maka implementasi peraturan daerah syariah marak terjadi di beberapa wilayah di Indonesia. Perda inilah yang kemudian dikenal dengan Perda syariah Islam.

Perda bernuansa syariah, atau lebih dikenal sebagai perda "syariah", adalah produk hukum pemerintah daerah di beberapa propinsi, kota, dan kabupaten di Indonesia yang terinspirasi dari syariah dalam Islam. Undang-undang ini, pemerintah daerah provinsi dan walikota/kabupaten diberikan keleluasaan dalam membentuk kebijakan publik, termasuk perda syariah dikeluarkan dengan harapan dapat menyelesaikan masalah-masalah multi-dimensi.

1 Nur Rohim Yunus, Penerapan Syariat Islam Terhadap Peraturan Daerah dalam Sistem Hukum Nasional Indonesia, Hunafa: Jurnal Studia Islamika, Volume Ke-12, Nomor 2: 2015. 
Tabel 1. Kategori perda syariah di Indonesia

\begin{tabular}{c|l|c|c}
\hline No & \multicolumn{1}{|c|}{ Kategori Perda } & Jumlah & Persentase \\
\hline 1 & Moralitas & 170 & 40 \\
\hline 2 & Zakat & 62 & 15 \\
\hline 3 & Keimanan & 59 & 14 \\
\hline 4 & Keuangan Islam & 39 & 9 \\
\hline 5 & Pendidikan Islam & 27 & 6 \\
\hline 6 & Busana Muslim & 25 & 6 \\
\hline 7 & Lainnya & 40 & 10 \\
\hline & Jumlah & 422 & 100 \\
\hline
\end{tabular}

Sumber: data diolah dari DJPP Kemenkumham

Penetapan kebijakan yang dilakukan pemerintah daerah dalam Perda mencakup aturan tentang: berbusana secara islami, membaca al-Qur'an, ramadhan, perjudian, prostitusi, dan lain-lain yang berbau maksiat ${ }^{2}$. Peraturan daerah berbasis syari'at Islam kebijakan yang bersifat publik baik dibidang politik, Hukum, dan Ekonomi (bidang produksi, distribusi, konsumsi, ekonomi, kebijakan fiskal, dan lain sebagainya).

Paper ini fokus terhadap analisis peran peraturan daerah syariah dalam upaya peningkatan daya saing ekonomi sehingga memunculkan rumusan masalah: "Bagaimana peran peraturan daerah syariah di Jawa Timur dalam upaya peningkatan daya saing ekonomi daerah?” Berbeda dengan riset yang dilakukan oleh Pisani \& Buehler tentang Why do Indonesian politicians promote sharia laws? An analytic framework for Muslim-majority democracies, menunjukkan hasil analisa pada politisi muslim yang mengharapkan Islam menjadi bagian dari hukum negara ${ }^{3}$. Cammack \& Feener ${ }^{4}(2012)$ tentang The Islamic Legal System in Indonesia, bahwa sistem hukum Indonesia banyak dipengaruhi oleh Islam. Maka dengan ini dapat menjadi salah satu bahan pertimbangan kebijakan pemerintah daerah dalam upaya

2 Denny Indrayana. Kompleksitas Peraturan Daerah Bernuansa Syariat Perspektif Hukum Tata Negara. Jurnal Yustisia. Edisi 81: 2010.

3 Elizabeth Pisani, Michael Buehler. Why do Indonesian Politicians Promote Sharia Law? An Analytic Framework For Muslim Majority Democracies. Journal of Third World Quarterly, 2016.

4 Cammack, Mark E Dan R Michael Feener, The Islamic Legal System In Indonesia. Journal of Pacific Rim Law \& Policy, Volume. 21 No. 1: 2012. 
mengakselerasi peningkatan ekonomi di daerah yang benar-benar bisa membawa maslahat secara ekonomi dan sosial menjadi negara Indonesia yang Baldatun Thayyibatun waa Rabbun Ghofur.

\section{Metode Penelitian}

Jenis penelitian ini secara keseluruhan merupakan jenis karya tulis deskriptif (descriptive research) dengan penelitian kualitatif ${ }^{5}$ Pendekatan penelitian ini menggunakan Yuridis Normatif yang merupakan Metode penelitian hukum yang menggunakan konsepsi legis positive dengan cara meneliti bahan pustaka atau bahan sekunder berupa literatur perundang-undangan berimplikasi pada permasalahan yang dibahas ${ }^{6}$. Penelitian ini merupakan penelitian yuridis normatif tentang persoalan-persoalan yang bertujuan untuk mengetahui tentang kebijakan pemerintah daerah dengan meninjau pola peraturan daeran berbasis syariah pada kebijakan ekonomi yang di praktikkan di beberapa wilayah di Indonesia, yaitu Provinsi Aceh dan Provinsi Jawa Timur.

Metode pendekatan dalam penelitian ini adalah pendekatan peraturan perundang-perundangan (statue approach $)^{7}$, suatu penelitian normatif tentu harus menggunakan pendekatan perundang-undangan, karena yang akan diteliti adalah berbagai aturan hukum yang menjadi fokus sekaligus tema sentral suatu penelitian. Pada penelitian hukum normatif, pengolahan data dilakukan dengan sistematika terhadap bahan-bahan hukum tertulis. Kegiatan yang dilakukan dalam analisis data penelitian hukum normatif dengan cara data yang diperoleh di analisis secara deskriptif kualitatif, yaitu analisa terhadap data yang tidak bisa dihitung. Hasil analisis bahan hukum akan diinterpretasikan menggunakan metode interpretasi (a) sistematis; (b) gramatikal; dan (c) teleologis. ${ }^{8}$

Deskriptif berarti teknik analisa dengan cara menjelaskan konsep perda syariah untuk pengembangan ekonomi syariah di daerah yang terkait secara apa adanya tanpa interpretasi dari penulis. Setelah proses pengolahan data, berikutnya adalah menganalisis data dan menginterpretasikannya. Data hasil analisis tersebut diinterpretasikan atau disimpulkan untuk menjawab keseluruhan masalah yang diteliti. Agar hasil analisis ini memperoleh kebenaran yang ilmiah, maka analisis

5 Lexy Moleong, Metode Penelitian Kualitatif (Edisi Revisi) (Bandung: Rosdakarya, 2013), h. 5.

6 Roni Hanitijo Soemitro, Metode Penelitian Hukum (jakarta: Ghalia Indonesia, 1994), h. 20; Amirudin dan Zainal Asikin, Pengantar Metode Penelitian Hukum (Jakarta: Raja Grafindo Persada, 2004), h. 34;; Soerjono Soekanto, Pengantar Penelitian Hukum (Jakarta: PenerbitUniversitas Indonesia, 2004), h. 45.

7 Peter Mahmud Marzuki. Penelitian Hukum. Jakarta: Kencana, 2008.

8 Jimly Asshiddiqie. Teori dan Aliran Penafsiran Hukum Tata Negara. Jakarta: Ind. Hill. Co, 1997. 
dalam penelitian ini dilakukan dengan memperhatikan beberapa tahapan yaitu tahap penyajian bukti atau fakta (skeptik), memperhatikan permasalahan yang relevan (analitik), dan tahap menimbang secara obyektif untuk berpikir logis kritik.

\section{Pembahasan}

\section{Kebijakan Pemerintah Sektor Publik}

Sebelum dibahas lebih jauh mengenai konsep kebijakan publik, kita perlu mengakaji terlebih dahulu mengenai konsep kebijakan atau dalam bahasa inggris sering kita dengar dengan istilah policy. Konsep kebijakan menurut Budiardjo (1972) dikutip dalam buku Faried Ali, secara konseptual sering dikonsepsikan dengan terminologi "kebijaksanaan" sebagai konsep filsafat yang di terminologikan dengan "wisdom" yang berarti "cinta kebenaran".

Perbedaan antara pengambilan atau pembuatan kebijakan (policy making) dengan pengambilan keputusan (decision making) ${ }^{10}$, dapatlah digambarkan dalam ilustrasi flowchart berikut:

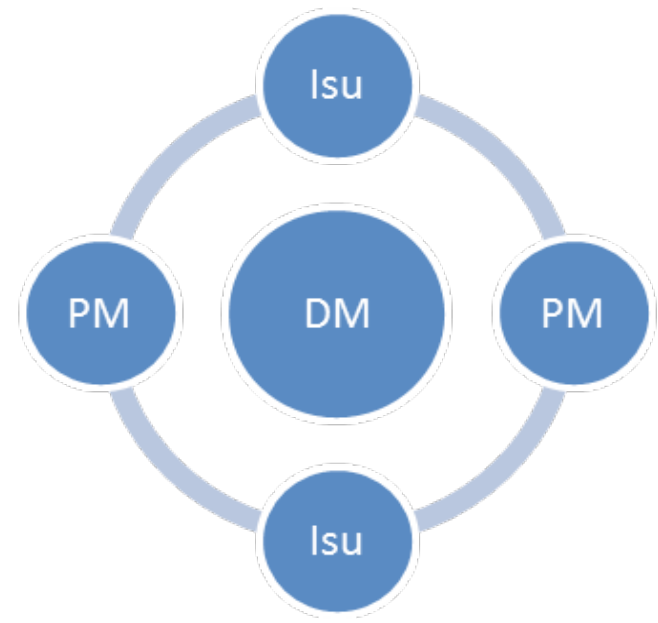

Gambar 1. Flowchart konsep pengambilan kebijakan dan pengambilan keputusan

Maksud dariflowchart diatas adalah dari isu ke isu melintasi policy making; kontinuitas, dari isu melintasi policy making melahirkan decision making; final. Ilustrasi ini memberikan pesan bahwa setiap dilakukan pengambilan kebijakan akan selalu terjadi pengambilan keputusan, tetapi setiap kali dilakukan pengambilan keputusan tidaklah berarti bahwa kebijakan akan berakhir. Kebijakan akan berlangsung 9 Faried Ali, Studi Kebijakan Pemerintah (Bandung: Reflika Aditama, 2012), h.7.

10 Faried Ali, Studi Kebijakan Pemerintah ..... h. 10. 
secara terus menerus dalam suatu proses yang diawali isu dan diakhiri dengan isu namun dari isu inilah melahirkan isu-isu baru yang mendorong silakukannya reformulasi atas kebijakan yang berjalan dan dengan demikian akan berlanjut dengan reimplementasi dan untuk akhirnya reevaluasi, demikian seterusnya.

Secara sederhana Faried Ali merumuskan bahwa kebijakan publik adalah kebijakan yang dikembangkan oleh badan dan lembaga pemerintah dalam artian yang luas yang berarti lembaga non-pemerintahan juga secara implisit termasuk di dalamnya dengan alasan karen mereka pun adalah juga. Sebagai pelaku dan faktor yang mempengaruhi ${ }^{11}$.

Pengertian kebijakan publik oleh pemerintah akan dapat dipahami secara mendalam jika dilakukan penganalisaan ketika kebijakan publik dipahami sebagai suatu variabel sehingga dengan demikian hasil analisa akan memberikan gambaran atas ruang lingkup kajian atau materi pembelajaran atas kebijakan tersebut.

Lingkup dari studi kebijakan publik sangat luas karena mencakup berbagai bidang dan sektor seperti ekonomi, politik, sosial, budaya, hukum, dan sebagainya. Disamping itu dilihat dari hirarkirnya kebijakan publik dapat bersifat nasional, regional maupun lokal seperti undang-undang, peraturan pemerintah, peraturan presiden, peraturan menteri, peraturan pemerintah daerah/provinsi, keputusan gubernur, peraturan daerah kabupaten/kota, dan keputusan bupati/walikota.

\section{Penerapan Syariah Islam dalam Bingkai Otonomi}

Syariah berasal dari kata syaria, berarti mengambil jalan yang memberikan akses pada sumber. Istilah syariah juga berarti jalan hidup atau cara hidup. Akar kata syari'ah dan turunannya dalam pengertian yang umum digunakan hanya dalam lima ayat al-Qur'an: Pertama, QS. al-Maidah ayat 48; Kedua, QS. asySyuura ayat 13; Ketiga, QS. Asy-Syura ayat 31; Keempat, QS. al-Jaatsiyah ayat 18. Menurut Fazlur Rahman ${ }^{12}$, syariah adalah nilai-nilai agama yang diungkapkan secara fungsional dan dalam makna kongkrit dalam kehidupan yang bertujuan untuk mengarahkan hidup manusia dalam kebaikan.

Membincangkan syariah di republik ini memang suatu keniscayaan. Sebagai umat Islam, menaati syariah sebagai hukum Tuhan di muka bumi merupakan suatu kewajiban yang tidak bisa dibantah.

Dalam amanat konstitusi Undang-Undang Dasar 1945, pasal 18 ayat 1 dan 2 dinyatakan: "Negara Kesatuan Republik Indonesia dibagi atas daerah-daerah

11 Faried Ali, Studi Kebijakan Pemerintah ..... h. 14.

12 Fazlur Rahman. Islam. University of Chicago Press, Chicago, 1997. 
provinsi dan daerah provinsi itu dibagi atas kabupaten dan kota, yang tiap-tiap provinsi, kabupaten, dan kota itu mempunyai pemerintah daerah yang diatur dengan undang-undang”. Makna pasal 18 dalam Undang-Undang Dasar 1945 menyebutkan bahwa Indonesia adalah negara kesatuan yang desentralisasi.

Pelaksanaan otonomi daerah tidak mencakup bidang-bidang tertentu, seperti politik luar negeri, pertahanan keamanan, peradilan, moneter, fiskal, dan agama. Bidang-bidang tersebut tetap menjadi urusan pemerintah pusat. Pelaksanaan otonomi daerah berdasar pada prinsip demokrasi, keadilan, pemerataan, dan keanekaragaman.

Munculnya perda syari'ah memiliki konsekuansi sebagai undang- undang di daerah yang mempunyai kekuatan mengikat yang mutlak kepada seluruh rakyat, institusi pemerintahan dan swasta serta kepada para pendatang yang berinteraksi di daerah. Perda syari'ah merupakan jenis perda khusus, yang bersumber pda local custom (kebiasaan lokal) atau hukum yang hidup (the living law) yang terdapat dalam wilayah tersbeut. Local custom terebut, lebih disandarkan pada komposisi jumlah masyarakat pada suatu daerah atau kekuatan hegemonik para elit politik daerah tersebut yang tersebar baik di partai, lembaga legislatif, ataupun eksekutif. Munculnya perda Syari'ah menurut Munawar tidak semata-mata lahir, akan tetapi merupakan akibat dari perjalanan politik umat Islam ${ }^{13}$.

Muhtada mengelompokkan perda syariah di Indonesia terbagi menjadi 7 aspek peraturan ${ }^{14}$; pertama, perda-perda yang terkait dengan moralitas. Ini meliputi perda-perda tentang pelarangan minuman keras, prostitusi, atau perjudian: kedua, perda-perda yang terkait dengan kebijakan zakat, infaq, dan shadaqah. Ketiga, perda-perda yang terkait dengan pendidikan Islam. Ini meliputi perda tentang madrasah diniyah dan baca tulis al-Quran: keempat, perda-perda yang terkait dengan pengembangan ekonomi Islam. Ini mencakup perda tentang Baitul Mal wat Tamwil (BMT) dan Bank Perkreditan Rakyat Syariah (BPRS): kelima, perda-perda tentang keimanan seorang Muslim. Ini termasuk peraturan tentang larangan kegiatan Ahmadiyah atau sekte-sekte Muslim yang dianggap sesat lainnya: keenam, perda-perda tentang busana Muslim, termasuk kewajiban mengenakan jilbab bagi perempuan: ketujuh, perda-perda syariah dalam kategori lain-lain. Perda-perda dalam kategori ini misalnya perda tentang masjid agung, pelayanan haji, dan penyambutan Ramadhan.

13 Ahmad Munawar. Fenomena Perda Syari'ah: Institusi Identitas pada Tingkat Local State. Jurnal Sosiologi Agama. Volume ke I, No. 1: 2007.

14 Dani Muhtada. The Mechanisms of Policy Diffusion: A Comparative Study of Shari'a Regulations in Indonesia, Dissertation Sumitted to The Graduate School. Department of Political Science, Northern Illinois University, 2014. 
Sementara ini ada beberapa perda syariah dan formalisasi tuntutan Syariat Islam yang juga diwujudkan melalui kebijakan pemerintah daerah yang berbentuk Surat Keputusan, Instruksi maupun Surat Edaran Gubernur, Bupati/Walikota. Yang setidaknya ada kesesuaian dengan topik yang dibahas oleh penulis yang diantaranya:

1. Provinsi Jawa Timur: Keputusan Gubernur Jawa Timur Nomor 188/600/ KPTS/013/2016 tentang Satuan Tugas Akselerasi Ekonomi Syariah Provinsi Jawa Timur.

2. Adanya perda syariah merupakan penguatan identitas Islam secara formal dengan demikian pemberlakuan perda syariah merupakan penegasan Islam sebagai simbol spirit perjuangan. Perda syari'ah merupakan bentuk islamisasi dibidang politik dengan menekankan pada prinsip ke-Islam-an yang mensejahterakan.

\section{Perda Syariah Untuk Ekonomi}

Otonomi daerah memberikan kewenangan yang dimiliki oleh pemerintah daerah akan semakin besar tanggung jawab akan bertambah banyak. Implikasi dari adanya kewenangan urusan pemerintahan yang begitu luas yang diberikan kepada daerah dalam rangka otonomi daerah dapat menjadi suatu berkah bagi daerah. Oleh karena itu kemauan politik (political will) dari pembuat kebijakan untuk menerapkan ajaran-ajaan Islam di bidang ekonomi akan berupaya menciptakan sistem ekonomi Islam yang secara inheren merupakan konsekuensi logis dari kesempurnaan Islam itu sendiri.

Islam memberikan prinsip tentang kebijakan fiskal atau anggaran pendapatan dan belanja bertujuan untuk mengembangkan suatu masyarakat yang didasarkan atas distribusi kekayaan berimbang dengan menempatkan nilai-nilai material dan spiritual pada tingkat yang sama, yang tidak lepas dari kendali politik ekonomi (assiyasatu al-iqtishadi) yang bertujuan, sebagaimana yang dikemukakan Abdurrahman Al-Maliki ${ }^{15}$, yaitu menjamin pemenuhan kebutuhan-kebutuhan primer (al-hajat al-asasiyah/basic needs) per individu secara menyeluruh, dan membantu tiap-tiap individu diantara mereka dalam memenuhi kebutuhan-kebutuhan sekunder dan tersiernya (al-hajat alkamaliyah) sesuai kadar kemampuannya.

Efisiensi dan efektifitas merupakan landasan pokok dalam kebijakan pengeluaran pemerintah. Dalam ajaran Islam hal tersebut dipandu oleh kaidahkaidah Syar'iyyah dan penentuan skala prioritas. Menurut al-Maliki, ada empat perkara yang menjadi asas politik ekonomi Islam. Secara umum pertama, setiap

15 Abdurrahman Al-Maliki. Politik Ekonomi Islam, Terjemahan oleh Ibnu Sholah. 2009, Bogor : al-Azhar Press, 2009. 
orang adalah individu yang memerlukan pemenuhan kebutuhan; kedua, pemenuhan kebutuhan-kebutuhan pokok dilakukan secara menyeluruh (lengkap); ketiga, mubah (boleh) hukumnya bagi individu mencari rizki (bekerja) dengan tujuan untuk memperoleh kekayaan dan meningkatkan kemakmuran hidupnya; keempat, nilainilai luhur (syariat Islam) harus mendominasi (menjadi aturan yang diterapkan) seluruh interaksi yang melibatkan individu-individu di dalam masyarakat.

\section{Komitmen Pemerintah Jawa Timur terhadap Ekonomi Islam}

Besarnya potensi Jawa Timur sebagai basis pengembangan ekonomi dan keuangan syariah di Indonesia ditambah lagi mayoritas penduduk Jatim sebesar 96\% beragama Islam. Memiliki Pondok Pesantren (Ponpes) lebih dari 6000 Ponpes. Bank Indonesia Jawa Timur bekerjasama dengan Pemprov Jatim membentuk Satuan Tugas Akselerasi Ekonomi Syariah 'Satu Akses' melalui keputusan Gubernur Nomor 188/600/KPTS/013/2016 tentang Satuan Tugas Akselerasi Ekonomi Syariah Provinsi Jawa Timur tanggal 21 Oktober 2016.

Tugas Satu Akses antara lain, menyusun Program Pengembangan dan Akselerasi Ekonomi Syariah di Jawa Timur berdasarkan roadmap yang ditetapkan, serta mengkoordinasikan dengan berbagai unsur dan stakeholder yang terlibat. Selain itu, memfasilitasi masyarakat dan pelaku ekonomi untuk mendapatkan akses pembiayaan dari lembaga keuangan berbasis syariah; serta memberikan rekomendasi kebijakan strategis kepada Gubernur Jatim dalam hal pengembangan ekonomi syariah.

Jawa Timur memiliki potensi dalam menetapkan Kebijakan Strategis Program Pengembangan dan Akselerasi Ekonomi Syariah, yaitu: 1) Kelembagaan dan sinergi dan sinkronisasi antar lembaga terkait dengan PPAES; 2) Sinkronisasi kebijakan pemerintah pusat dan daerah; 3) Penyadaran dan edukasi ekonomi Islam; 4) Penyiapan SDI. 5) Membangun basis dan jaringan bisnis; 6) Manajemen dan tata kelola; 7) Penghimpunan dana oleh lembaga ekonomi Islam agar lebih berkontribusi dalam perekonomian Jawa Timur. ${ }^{16}$

16 Pusat Pengkajian dan Pengembangan Ekonomi Islam (P3EI). Ekonomi Islam. (Jakarta: PT. Raja Grafindo Persada, 2008). 


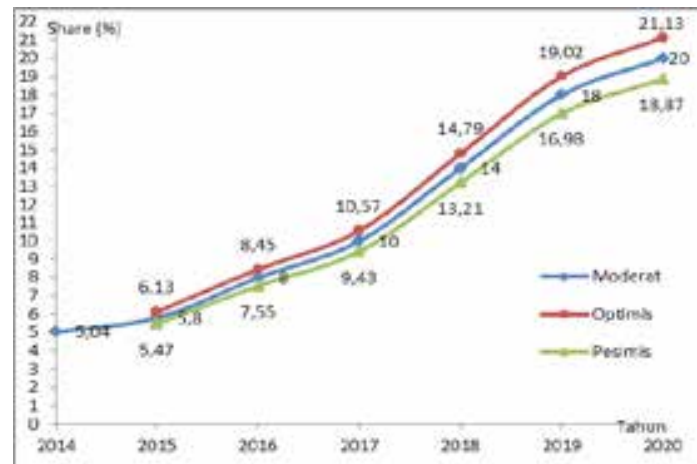

Gambar 2. Grafik sasaran share ekonomi syariah dalam PPAES Jawa Timur

Penghimpunan dana oleh lembaga ekonomi Islam agar lebih berkontribusi dalam perekonomian Jawa Timur. 10 sumber dana potensial untuk perbankan syariah: a) Dana Desa; b) Dana APBD Provinsi Jawa Timur; c)Pendirian BPRS oleh Kabupatan dan Kota di Jawa Timur; d)Industri dan Masyarakat; e)Lembaga Pendidikan Islam;f)Lembaga Pendidikan Tinggi;g) baitulmaal wat tamwil(BMT) dan koperasi syariah yang dibentuk berdasarkan lembaga fungsional Agama Islam dan jumah satu desa satu unit; h) baitul maal wat tamwil (BMT) dengan badan hukum Koperasi Jasa Keuangan Syariah (KJKS) yang telah ada dan atau akan dibentuk sendiri oleh masyarakat; i)Dana yang dikumpulkan oleh Lembaga Zakat baik Badan Amil Zakat (BAZ) maupun Lembag Amil Zakat (LAZ); j) Masjid.

Tabel 2. Estimasi Total Dana

\begin{tabular}{|c|c|c|c|c|c|c|c|c|c|c|c|c|c|}
\hline \multirow[b]{2}{*}{ no } & \multirow[b]{2}{*}{ Reteronean } & \multicolumn{2}{|l|}{2015} & \multicolumn{2}{|c|}{2016} & \multicolumn{2}{|c|}{2017} & \multicolumn{2}{|c|}{2018} & \multicolumn{2}{|l|}{2019} & \multicolumn{2}{|c|}{2020} \\
\hline & & $\begin{array}{l}\text { Oenos (npp } \\
\text { Miliar) }\end{array}$ & Porsi & $\begin{array}{l}\text { Dono } \\
\text { (Ro. } \\
\text { Malion) }\end{array}$ & Dorsi & $\begin{array}{c}\text { Dono } \\
\text { TRo. } \\
\text { Malior) }\end{array}$ & Porsi & $\begin{array}{l}\text { Dono } \\
\text { 100. } \\
\text { Milior) }\end{array}$ & Porsi & $\begin{array}{c}\text { Donos } \\
\text { (100. } \\
\text { Malis) }\end{array}$ & porsi & $\begin{array}{c}\text { Oans }(10 p \\
\text { Milier) }\end{array}$ & Porsi \\
\hline 1 & Oans Oress & 1198 & 16,06 & 2737 & 16,7 & 4660 & 17,92 & sose & 13,28 & 6420 & 10.28 & $738:$ & 8.86 \\
\hline 2 & 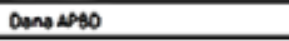 & 1186 & 15.96 & 2728 & 16,6 ? & 4306 & 18.16 & 7215 & 16,00 & 12406 & 19.98 & 1908 & 22.88 \\
\hline 3 & OPes & 25 & 0.3 & 6 & $0.4 \mathrm{z}$ & 118 & 0.46 & 184 & 0.42 & 266 & 0.45 & 359 & 0.45 \\
\hline 4 & industri dan Masarake & 2722 & $36.6-$ & 6189 & 37.82 & 7470 & 28.80 & 1597 & 35.62 & 21412 & 34,27 & $28 \mathrm{s00}$ & Hess \\
\hline 5 & Pendidikan islom & 691 & 9,30 & 1548 & 9,46 & 3468 & 13,3, & 5827 & 12,90 & 8702 & 13,93 & 12185 & 14.61 \\
\hline 6 & Derouruentines & Ss: & $7,4,2$ & 1238 & 7.5s: & 2078 & 8.00 & $30 \%$ & 6.91 & 4398 & 6.94 & 4559 & S.85: \\
\hline 7 & 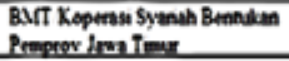 & so & 0,67 & 165 & 1,0 & 365 & 1 & 678 & $1.5 \mathrm{co}$ & 1009 & 1,7 & 162 의 & 1.9 \\
\hline 8 & BMIT yans Telah Ada & 500 & 6.73 & 600 & 3.67 & 720 & 2.78 & 864 & 1.98 & 1037 & 1.6 & 124 & 1.49 \\
\hline 9 & Dana Lembaga Zatar & 512 & 6,8 & 1098 & 6,72 & 25s: & 2.00 & $\operatorname{sos} 0$ & 11,26 & 6769 & $10.8 \mathrm{~s}$ & 7850 & 9.40 \\
\hline 10 & Dano lointun & 20 & 0 & nat & ax & . & 14. & $=$ & 2, & 100 & 1.20: & $1 \mathrm{an}$ & 10 \\
\hline & Total & 8.17: & 100 & 17.184 & 100 & 26836 & 100 & 4584 & 100 & 63.565 & 100 & s4.5sed & 100 \\
\hline
\end{tabular}

Sumber: data diolah 
Terdapat lima komitmen program pengembangan dan akselerasi ekonomi syariah Jawa Timur, seperti yang tercantum dalam gambar dibawah ini.

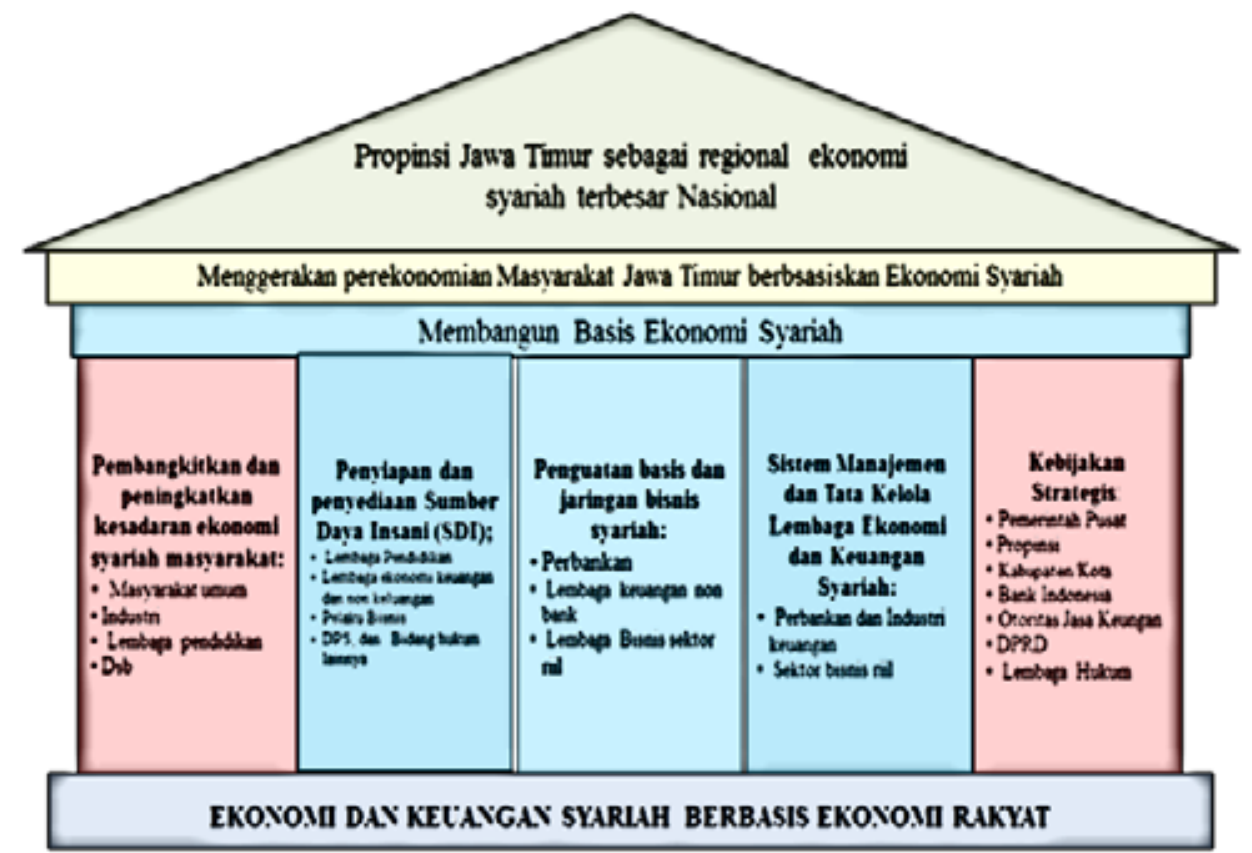

Gambar 3. Bagan pengembangan dan akselerasi ekonomi syariah di Jawa Timur

Kelima komitmen itu memang merupakan komitmen bersama seluruh stakeholder, namun dalam implementasinya maka perlu pembagian peran sesuai dengan proporsi dan kedudukan masing-masing. Pembagian peran tersebut dapat dibuat sebagai berikut: 1) menyiapkan sumber daya insani yang peran utamanya dilakukan oleh Bank Indonesia, Otoritas Jasa Keuangan, dan Akademisi serta pondok pesantre; 2) peningkatan kesadaran serta komitmen ekonomi syariah masyarakat oleh Pemuka Agama dan Forum Akselerasi Ekonomi Syariah; 3) Pembangunan dan penguatan basis, jaringan, dan keterkaitan bisnis syariah yang dilakukan oleh praktisi ekonomi dan keuangan syariah; 4) peningkatan kualitas sistem manajemen dan tata kelola lembaga ekonomi dan keuangan syariah yang dilakukan oleh praktisi ekonomi dan keuangan syariah; 5) pengembangan kebijakan strategis yang mendukung akselerasi ekonomi syariah yaitu pelaku utamanya adalah Pemerintah Pusat dan Daerah serta Bank Indonesia dan Otoritas Jasa Keuangan. Dengan begitu, penerapan kebijakan yang tertuang dalam qanun dan peraturan daerah telah dilaksanakan oleh pemerintah daerah sesuai dengan 
kebijakan keuangan publik dalam tinjauan ekonomi Islam.

\section{Simpulan}

Penerapan syariah Islam salah satu cara untuk menjadikan syariah Islam sebagai konstitusi (dustur) dan undang-undang negara (qanun). Konstitusi syariah hanya memuat pokok-pokok terpenting dari syariah Islam yang bisa menggambarkan Syariah Islam secara utuh dan menyeluruh (kamil dan syamil), meskipun dengan redaksi yang sangat global dan ringkas disitulah sebenarnya manhaj penerapan syariah Islam dalam berbagai bidang dipaparkan.

Sudah selayaknya signifikansi perda dan qanun bernuansa syariat Islam harus diletakkan secara proporsional. Dengan kata lain, keberadaan perda dan qanun bernuansa syariat Islam harus dipandang dalam koridor sejauh mana mampu mewujudkan kemaslahatan dalam kehidupan bermasyarakat terutama menyangkut ekonomi dan perkembangan keuangan syariah.

Jawa Timur merupakan daerah di Indonesia yang menjadikan beberapa regulasi kebijakan di daerah tersebut telah menunjukkan komitmen besar dalam mengupayakan peningkatan ekonomi daerah dengan menerapkan ekonomi syariah. Namun selama ini masih sangat rendah aktifitas sosialisasi kepada masyarakat. Oleh karena itu ke depan diharapkan perlu dilakukan kinerja yang lebih gencar dan efektif diantara para stakeholder baik melalui media elektronik maupun media cetak dalam hal sosialisasi dan edukasi. Hal ini adalah dalam rangka meningkatkan pengetahuan dan pemahaman masyarakat terhadap syariah dalam bidang ekonomi. Wallahu'lam bisshowab.

\section{Daftar Pustaka}

\section{Buku}

Al-Haritsi, Jaribah bin Ahmad. Fikih Ekonomi Umar bin Khathab. Jakarta: Khalifa, 2003.

Ali, Achmad. Menguak Teori Hukum (Legal Theory) \& Teori Peradilan (Judicialprudence): Termasuk Inter-pretasi Undang-Undang (Legisprudence). Jakarta: Kencana, 2008.

Ali, Faried. Studi Kebijakan Pemerintah. Bandung: Reflika Aditama, 2012.

Al-Maliki, Abdurrahman. Politik Ekonomi Islam, Terjemahan oleh Ibnu Sholah, Bogor: al-Azhar Press, 2009. 
Amirudin dan Zainal Asikin. Pengantar Metode Penelitian Hukum. Jakarta: Raja Grafindo Persada, 2004.

Asshiddiqie, Jimly. Teori dan Aliran Penafsiran Hukum Tata Negara. Jakarta: Ind. Hill. Co, 1997.

Edwin Nasution, Mustafa. Pengenalan EksklusifEkonomi Islam. Jakarta: Kencana, 2007.

Forum on Religion and Public Life. The Future of the Global Muslim Population, January 2011.

Marzuki, Peter Mahmud. Penelitian Hukum. Jakarta: Kencana, 2008.

Moleong, Lexy. Metode Penelitian Kualitatif(Edisi Revisi). Bandung: Rosdakarya, 2003.

Muhtada, Dani. The Mechanisms of Policy Diffusion: A Comparative Study of Sharia Regulations in Indonesia, Dissertation Sumitted to The Graduate School. Department of Political Science, Northern Illinois University

Nafik HR dkk, Muhammad. Edukasi Ekonomi dan Keungan Syariah: Program Pengembangan dan Akselerasi Ekonomi Syariah Jawa Timur. Surabaya: Bank Indonesia KW Jatim, 2016.

Pusat Pengkajian dan Pengembangan Ekonomi Islam (P3EI. Ekonomi Islam. Jakarta: PT. Raja Grafindo Persada, 2008.

Rahman,Fazlur. Islam. Chicago: University of Chicago Press, 1997.

Soemitro, Roni Hanitijo. Metode Penelitian Hukum. Ghalia Indonesia. Jakarta, 2008.

Soerjono Soekanto, 2007. Pengantar Penelitian Hukum. Jakarta: Penerbit

Universitas Indonesia

Tabangun Aceh. Aceh Menuju Ekonomi Islam, Edisi 48, Juli 2015.

\section{Artikel}

Cammack, Mark E Dan R Michael Feener. The Islamic Legal System In Indonesia. Journal of Pacific Rim Law \& Policy. Volume 21 Nomor 1: 2012. 
Indrayana, Denny. Kompleksitas Peraturan Daerah Bernuansa Syariat Perspektif Hukum Tata Negara. Jurnal Yustisia. Edisi 81. September-Desember 2010.

Munawar, Ahmad. Fenomena Perda Syari'ah: Institusi Identitas pada Tingkat Local State. Jurnal Sosiologi Agama. Volume 1 Nomor 1: 2007.

Pisani, Elizabeth Dan Michael Buehler. Why do Indonesian Politicians Promote Sharia Law? An Analytic Framework For Muslim Majority Democracies. Journal of Third World Quarterly, 2016.

Rumadi. Perda Syariat Islam: Jalan Lain menuju Negara Islam?, Tashwirul Afkar. Jurnal Refleksi Pemikiran Keagamaan dan Kebudayaan: Perda Syariat Menuai Makna. Edisi 1 Nomor 20: 2006

Shams, Rasul. A Critical Assessment of Islamic Economics. Hamburg Institute of International Economics (HWWA). Discussion Paper 281, 2006.

Situmeang, Taurusman. Proyek Penanggulangan Kebijakan Penanganan Kemiskinan Di Perkotaan; Studi Implementasi Kebijakan Proyek Penanggulangan Kemiskinan Di Perkotaan Di Desa Jatikerto Kecamatan Kromengan Kabupaten Malang. Jurnal Reformasi. Volume 3 Nomor 1: Januari-Juni 2013.

Yunus, Nur Rohim. Penerapan Syariat Islam Terhadap Peraturan Daerah dalam Sistem Hukum Nasional Indonesia. Hunafa: Jurnal Studia Islamika. Vol. 12, No. 2, Desember 2015.

\section{Peraturan Perundang-undangan}

Undang-Undang Dasar 1945.

Undang-Undang Republik Indonesia Nomor 23 Tahun 2014. 